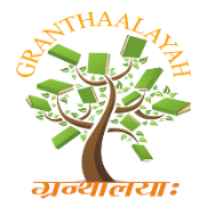

$$
\begin{gathered}
\text { INTERNATIONAL JOURNAL OF RESEARCH } \\
\text { GRANTHAALAYAH } \\
\text { A knowledge Repository }
\end{gathered}
$$

Science

\title{
EFFECT OF STORAGE DURATION ON MECHANICAL PROPERTIES OF BELLO EGGPLANT FRUIT UNDER QUASI COMPRESSION LOADING
}

\author{
Umurhurhu Benjamin ${ }^{1}$, Uguru Hilary ${ }^{* 2}$ \\ ${ }^{1}$ Department of Mechanical Engineering Technology, Delta State Polytechnic, Ozoro, Nigeria. \\ ${ }^{* 2}$ Department of Agricultural and Bio-environmental Engineering Technology, Delta State \\ Polytechnic, Ozoro, Nigeria
}

\begin{abstract}
The mechanical properties of eggplant fruit (cv. Bello) harvested at physiological maturity stage were evaluated in three storage periods $(3 d, 6 d$ and $9 d)$. These mechanical parameters (rupture force, rupture energy and deformation at rupture point) were measured under quasi compression loading, using the Universal Testing Machine (Testometric model). The fruit's toughness and rupture power were calculated from the data obtained from the rupture energy and deformation at rupture point. Results obtained showed that mechanical properties of the Bello eggplant fruit exhibited strong dependence on the storage period. The results showed that as the Bello fruit stored longer, its rupture force and rupture energy decreased from $812 \mathrm{~N}$ to $411 \mathrm{~N}$, and $5.58 \mathrm{Nm}$ to 3.11 $\mathrm{Nm}$ respectively. While the rupture power decreased from $1.095 \mathrm{~W}$ to $0.353 \mathrm{~W}$. On the contrary, the toughness and deformation at rupture increased from $0.270 \mathrm{~mJ} / \mathrm{mm} 3$ to $0.403 \mathrm{~mJ} / \mathrm{mm} 3$, and $16.99 \mathrm{~mm}$ to $25.22 \mathrm{~mm}$ respectively during the 9 days storage period. The knowledge of the mechanical properties of fruits is important for their harvest and post-harvest operations, therefore, information obtained from this study will be useful in the design and development of machines for the mechanization of eggplant production.
\end{abstract}

Keywords: Compression Loading; Bello Eggplant Fruit; Rupture Force; Toughness; Power.

$\begin{array}{llll}\text { Nomenclature } & & \\ \mathrm{L} & \text { Length }(\mathrm{mm}) & \mathrm{T} & \text { Thickness }(\mathrm{mm}) \\ \mathrm{W}= & \text { Width }(\mathrm{mm}) & \mathrm{T}_{\mathrm{o}} & \text { Toughness }(\mathrm{mJ} / \mathrm{mm} 3) \\ \mathrm{E}= & \text { Rupture energy absorbed }(\mathrm{Nm}) & \mathrm{V} & \text { Volume }(\mathrm{mm} 3) \\ \mathrm{P}= & \text { Power }(\mathrm{W}) & \mathrm{S} & \text { loading rate }(\mathrm{mm} / \mathrm{min}) \\ \mathrm{D} & \text { deformation at rupture point }(\mathrm{mm}) & & \end{array}$

Cite This Article: Umurhurhu Benjamin, and Uguru Hilary. (2019). "EFFECT OF STORAGE DURATION ON MECHANICAL PROPERTIES OF BELLO EGGPLANT FRUIT UNDER 
QUASI COMPRESSION LOADING.” International Journal of Research - Granthaalayah, 7(5), 311-320. https://doi.org/10.29121/granthaalayah.v7.i5.2019.850.

\section{Introduction}

Eggplant (Solanum aethiopicum L.) is one of the indigenous crops planted in Africa countries. The consumption of eggplant is steadily increasing because of greater awareness of the health beneficial effects associated with increased consumption of fruits and vegetables (Singh et al., 2009). Eggplant's fruits and leaves are highly valued constituents of the Nigerian foods and indigenous medicines; and are commonly consumed almost on daily basis by both rural and urban families (Tindal, 1965). The fruits are either eaten raw or fried as ingredient of soups and vegetable sauces. There are several varieties of African eggplant, displaying different traits like corolla diameter, petiole length, leaf blade width, plant branching, fruit shape and colour (Osei et al., 2010). The consumption of eggplant is steadily increasing because of greater awareness of the health beneficial effects associated with increased consumption of fruits and vegetables (Singh et al., 2009). The pharmacological properties of eggplant had been attributed to the presence of certain chemical substances, such as, fiber, ascorbic acid, phenols, anthocyanin, glycoalkaloids and $\alpha$-chaconine in the plant (Alozie et al., 1978; Sanchez-Mata et al., 2010; Chinedu et al., 2011). When compared to other fruits, eggplant fruit has relatively high carbohydrate $(7.2 \mathrm{~g} / 100 \mathrm{~g})$, crude fibres $(2.0 \mathrm{~g} / 100 \mathrm{~g})$, calcium $(28 \mathrm{mg} / 100 \mathrm{~g})$, iron $(1.5 \mathrm{mg} / 100)$, carotene $(0.35 \mathrm{mg} / 100 \mathrm{~g})$ and ascorbic acid (8 mg/100g) content (Hornal et al., 2007; Msogoya et al., 2014).

During post-harvest operations, eggplant fruit experienced two major forces, namely; compression and puncture forces. Mechanical damage are unpleasant for both fresh fruits and vegetables, as it cause both immediate and subsequent physiological responses in wounded and adjacent tissues, leading to complex physiological, metabolic, and enzymatic changes (Pérez-López et al., 2014). This increased the respiration at the injured sites, excessive tissue softening, browning of the tissue, wilting, discoloration, development of off-flavor, texture breakdown and, as a consequence, decreasing the visual appearance aspects, their commercial value, and the quality of final products (Allende et al., 2004; Hu et al., 2010; Li et al., 2010). Therefore, the knowledge of the mechanical properties of agricultural materials can decrease the effects of unwanted mechanical loading, quantity of mass wastage and energy consumption during processing operation like peeling and milling operations (Emadi et al., 2005). The mechanical behaviours of agricultural materials are dependent on the histological, anatomical, and biochemical specifications of their living cells (Varela et al., 2007). In addition, since agricultural materials structure are heterogeneous structure and are frequently anisotropic, mechanical stresses are distributed inhomogeneous within their tissue (Dan and Kohyama, 2007; Li et al., 2013).

There were several researches focusing on the mechanical properties of fruits as a function of loading orientation, maturity stage and storage period. Eboibi and Uguru, (2017) studied the effects of storage conditions and fruit region on the physic-mechanical properties of Nandini cucumber fruit. They reported that the failure strength, compressive strength, compressive energy and Young modulus of cucumber fruits stored at ambient condition declined by 53.86, 54.01, 65.35 and 47.92 $\%$ respectively within nine storage days. Some physico-mechanical properties of Santa Maria pear cultivar were studied by Ozturk et al., (2009), and their result gives the bulk density, rupture force and fruit hardness as $365.84 \mathrm{kgm}^{-3} ; 23.04 \mathrm{~N}$ and $9.87 \mathrm{~N} / \mathrm{mm}$. Tabatabaekoloor, (2014) reported that 
kiwifruit firmness declined by $59 \%$ when stored at ambient condition and $51 \%$ at cold conditions for 16 days. According to (Singh and Reddy, 2006) increasing storage duration of orange fruit, the force and energy needed to cut the orange fruit decreases; while Arendse et al., (2014) reported $53.56 \%$ decreased in the toughness of pomegranate fruits stored for 5 months in cold storage. Masoudi et al., (2007) recorded $66.57 \%$ drop in the toughness of Golden Delicious apple cultivar stored for six months at ambient condition. According to Ashtiani et al., (2016) the rupture force and Young's modulus of eggplant cv. Siah-e-Mashhad fruit decreased monotonically with the increasing of storage time. Salvador et al., (2007) studied the changes in color and texture of banana during storage at $10^{\circ} \mathrm{C}$ and $20^{\circ} \mathrm{C}$, and reported that during storage, the peel colour change (from green to yellow) was gradual in the M. Cavendish samples, whereas the M. Paradisiacal variety remained green for the first 8 days and then changing rapidly to a yellow from day 12 onwards.

From literature review so far, information related to the effect of storage period on mechanical properties of locally cultivated eggplant fruit is lacking. Therefore, the specific objectives of this study were to: (1) measure the mechanical properties (rupture force, rupture energy, deformation at rupture point, toughness and rupture power) of Bello eggplant fruit under compression test; and (2) evaluate the effect of storage time on the mechanical properties of Bello eggplant fruit.

\section{Materials and Methods}

\subsection{Collection and Sampling}

The Bello eggplant fruits used for this research were harvested from the research farm of Delta State Polytechnic, Ozoro, Nigeria, at full maturity stage (Figure 1). The harvested eggplant fruits were selected on the basis of uniformity of size and shape, washed with chlorine solution (concentration of 100 parts per million) to eliminate microbial growth and other infections during storage (Eboibi and Uguru, 2017). The washed and dried Bello fruits were packed in woven basket and stored at ambient temperature of $24^{\circ} \mathrm{C} \pm 5^{\circ} \mathrm{C}$ and $65-75 \%$ humidity for 9 days. The mechanical properties of the Bello fruits were determined at intervals of three days (0, 3, 6 and $9 \mathrm{~d})$.

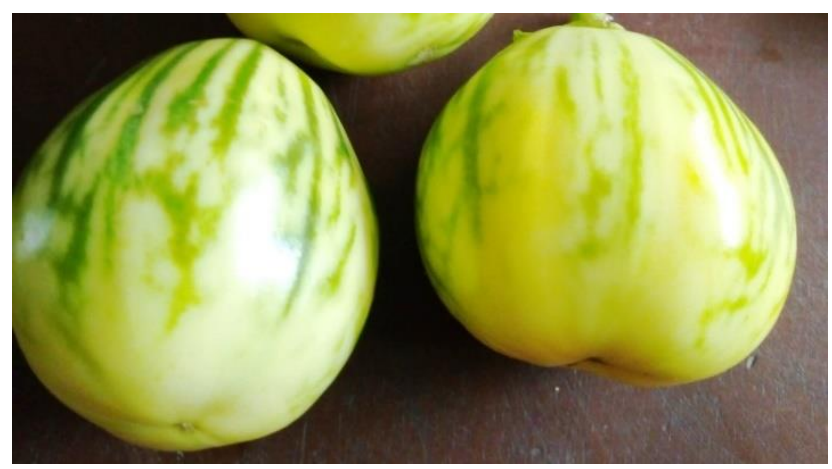

Figure 1: Bello eggplant fruit

\subsection{Mechanical Properties Determination}

The mechanical test of the Bello eggplant fruit was done using a Universal Testing Machine (Testometric model), equipped with a $500 \mathrm{~N}$ loading cell and integrator. During the test, each fruit 
sample was placed under the compression tool of the machine, ensuring that it was in alignment with the tool, and compressed at a loading rate of $20 \mathrm{~mm} / \mathrm{min}$ (Eboibi and Uguru, 2017). The compression (loading) continued until the fruit ruptured, when the compression stopped automatically. During the compression, a load-deformation curve was plotted by the microprocessor of the machine in relation to the response of the Bello fruit to the compression (Eboibi and Uguru, 2017). The following mechanical parameters were calculated by the machine read from the screen.

1) Rupture force

2) Rupture energy

3) Deformation at rupture point

Bello eggplant fruit like other agricultural materials has complex biomechanical systems and cannot be characterized by simple constants (Mohsenin, 1986), therefore, it is necessary to introduce some new concepts such as failure and rupture points (Nyorere and Uguru, 2018; Uguru and Iweka, 2019). According to Steffe, (1996) bioyield point (also expressed as the failure point) is related to a failure in the microstructure of the material associated with an initial disruption of cellular structure; and the rupture point of the material, correlates to the macroscopic failure (breaking point) in the sample, the failure strength was taken as the stress at which the sample failed in its internal cellular structure (Steffe, 1996; Eboibi and Uguru, 2017). The test was replicated ten times and the mean value of each parameter was recorded.

Toughness of the Bello eggplant fruit was calculated as the energy absorbed by fruit up to the rupture point as shown in Equation 1 (Olaniyan and Oje, 2002). The rupture power required to rupture the Bello fruit was calculated by using equation 2; while the volume (V) of the fruit was calculated using equation 3 (Khazaei et al., 2002).

$T_{o}=\frac{E}{V}$

$P=\left(\frac{E \times S}{6000 D}\right)$

$V=\frac{\pi \times L \times W \times T}{6}$

\subsection{Statistical Analysis}

All data obtained from this study were subjected to statistical analysis using the using the Statistical Package for Social Statistics (SPSS version 20.0) and Duncan's Multiple Range Test (DMRT) was used to compare the mean at $95 \%$ confidence level.

\section{Results and Discussions}

Analysis of variance (ANOVA) result of the data obtained from this study showed that for the storage duration had significant effect $(\mathrm{P} \leq 0.05)$ of all the mechanical parameters investigated (Table 1). The plots (charts) of the results of the mechanical test of the Bello fruit are presented in Figures 2 to 6. From the plots, it can be clearly seen that the all parameters investigated, except 
deformation at rupture point and toughness, decreased monotonically with the increasing of storage time.

Table 1: ANOVA result of the effect of storage period on the mechanical properties of Bello fruit

$*$ =Significant at $\mathrm{P} \leq 0.05$

\begin{tabular}{|l|l|l|}
\hline Parameter & df & Sig \\
\hline Rupture force & 3 & $5.11 \mathrm{E}-06^{*}$ \\
\hline Rupture energy & 3 & $1.09 \mathrm{E}-08^{*}$ \\
\hline Deformation at rupture & 3 & $3.95 \mathrm{E}-07^{*}$ \\
\hline Toughness & 3 & $0.000341^{*}$ \\
\hline Power & 3 & $4.52 \mathrm{E}-10^{*}$ \\
\hline
\end{tabular}

\subsection{Rupture Force}

As shown in Figure 2, the storage period had significant effect on the fruit rupture force. The rupture force decreased significantly $(\mathrm{P} \leq 0.05)$ with increasing storage duration from $0 \mathrm{~d}$ to $6 \mathrm{~d}$, but further increase in storage duration (from $6 \mathrm{~d}$ to $9 \mathrm{~d}$ ) had no significantly effect on the rupture force. The maximum and minimum values of the Bello fruit rupture force were $812 \mathrm{~N}$ and $411 \mathrm{~N}$, obtained at the harvest day and 9 days of storage respectively. In similar trend, Singh and Reddy, (2006) reported that increasing storage duration of orange fruit, the force and energy needed to cut fruit decreased. Rupture force of fruits is an essential parameter in the design and development of their crushing and other processing machines.

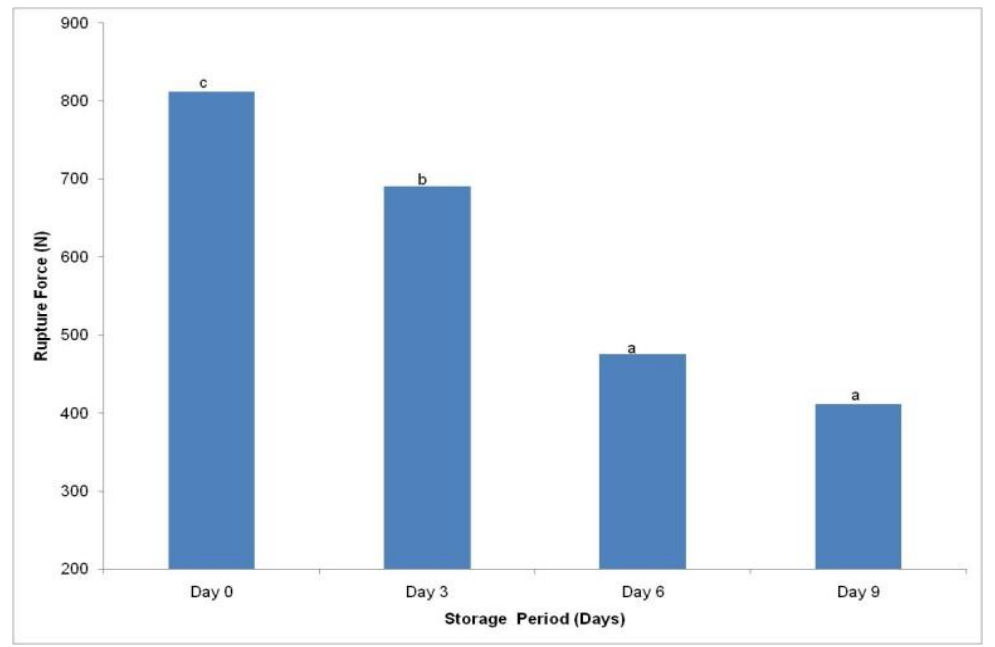

Figure 2: Effects of storage duration on the rupture force of Bello eggplant fruit Columns with the same common letters means that they are not significant different at $(\mathrm{P} \leq 0.05)$.

\subsection{Rupture Energy and Power}

The plot in Figures 3 and 4 showed the rupture energy and power of Bello eggplant. The carts showed that rupture energy and power of the Bello eggplant fruit, decreased with increase in storage duration for $0 \mathrm{~d}$ to $9 \mathrm{~d}$. The declined in the rupture energy of the Bello fruit during storage could be attributed to increase of evaporation, transpiration and metabolic activity of fruits during storage at ambient temperature, which will be made the fruit texture softer due to the cellular water 
loss and disintegration the cell wall structure composition (Brusewitz et al., 1989). It is clear from Figures 3 and 4 that with increasing storage duration from $0 \mathrm{~d}$ to $9 \mathrm{~d}$, the rupture energy and power decreased significantly ( $\mathrm{P} \leq 0.05)$ from $5.58 \mathrm{Nm}$ to $3.11 \mathrm{Nm}(46.75$ decrease); while the power decreased significantly $(\mathrm{P} \leq 0.05)$ from $1.095 \mathrm{~W}$ to $0.353 \mathrm{~W}(76.6 \%$ decrease).. These results indicated that the rigidity of the cellular structures of the Bello fruit diminished over 9 days of storage due to loss of moisture through transpiration and enzymatic changes and thus the fruit structure became softer as storage duration progresses (Cen et al., 2013). Similar results were recorded by Jahangiri et al., (2016) for Viola cucumberfruit, where the failure stress value decreased significantly ( $\mathrm{P}<0.01$ ) from $0.85 \mathrm{MPa}$ to $0.53 \mathrm{MPa}$ during nine storage days. Yurtlu and Erdogan, (2005) reported that the apple and pear tissue strength decreased during storage duration due to decrease in the thickness of cell wall. Masoudi et al. (2007) in their study recorded decreased in the modulus of elasticity, failure stress and failure energy of apples with increasing storage duration

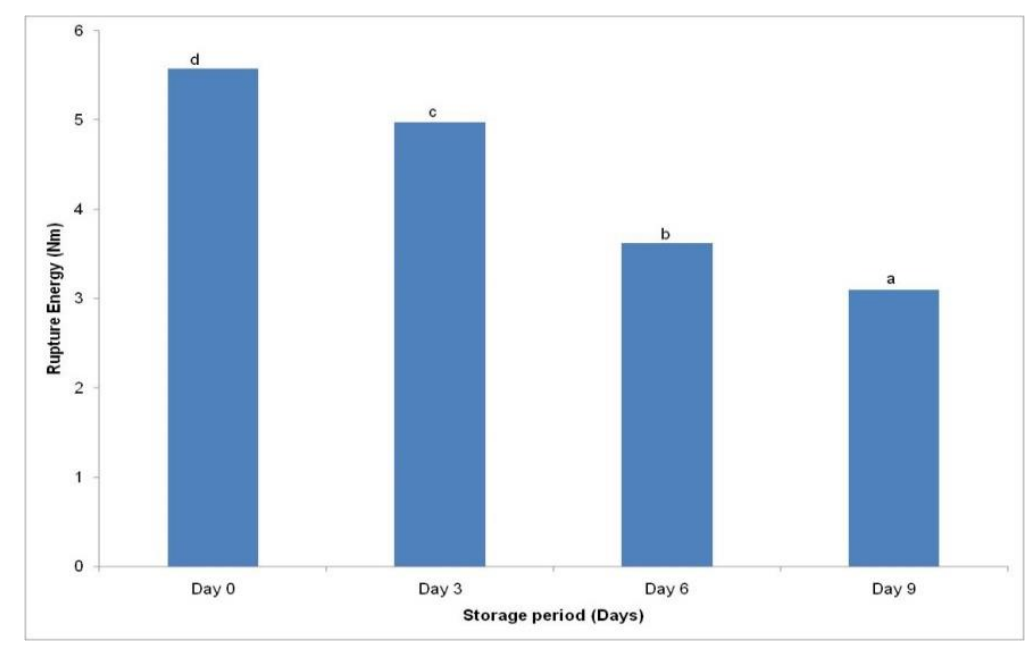

Figure 3: Effects of storage duration on the rupture energy of Bello eggplant fruit Columns with the same common letters means that they are not significant different at $(\mathrm{P} \leq 0.05)$.

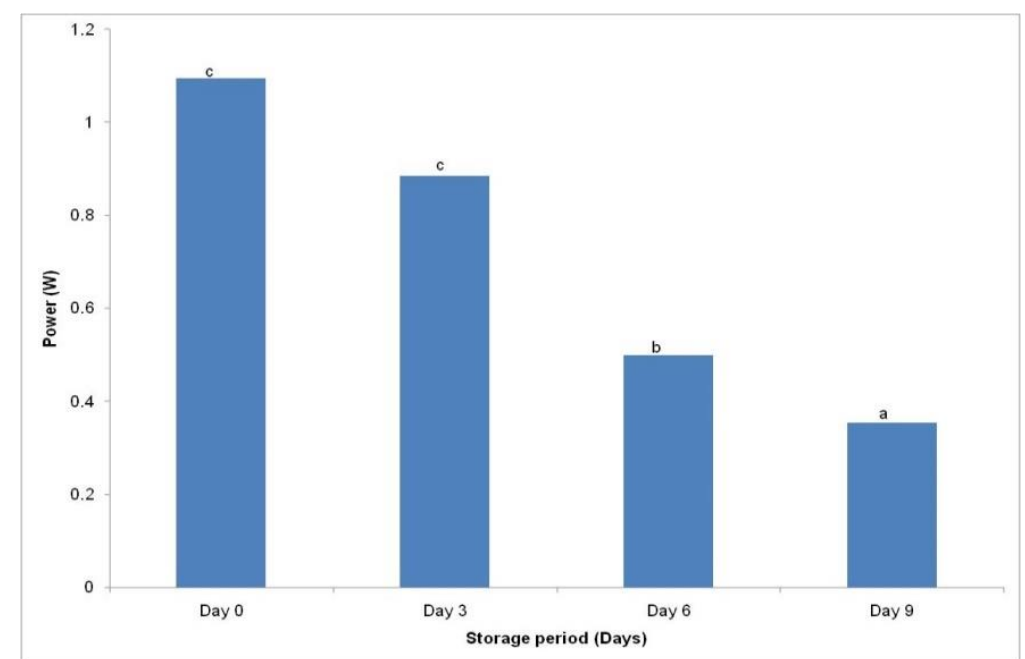

Figure 4: Effects of storage duration on the rupture power of Bello eggplant fruit Columns with the same common letters means that they are not significant different at $(\mathrm{P} \leq 0.05)$. 


\subsection{Deformation at Rupture Point}

Figure 5 showed the variation in the deformation of Bello fruit at rupture point during storage period. As seen in the chart in Figure 5, the deformation of the Bello fruit increased with increased in storage period. The deformation increased from $16.99 \mathrm{~mm}$ to $25.22 \mathrm{~mm}$ within the 9 days storage period. This may be attributed to the declined in the rigidity of the cellular structure of the Bello fruit. Similar results were recorded by Ashtiani et al., (2016) for Siah-e-Mashhad eggplant fruit, where the deformation increased from 11.42 to $14.82 \mathrm{~mm}$ within 9 storage days. According to Zdunek et al., (2010) during storage the maximum force needed to rupture fruits decreased, but its position on the force-displacement curve increased, therefore the stress decreased and the strain increased by time passing. The decrease in stiffness of the tissue by the effect of the storage time depends largely on the extent to which the structural changes occur in the cell wall constituents (Pérez-López et al., 2014). The maturity stage of the fruit at harvest time, due to its influence on the speed at which occurs the loss in the form of parenchyma cells that give overall rigidity to the tissue (Kays and Paull, 2004; Redgwell and Fischer, 2002).

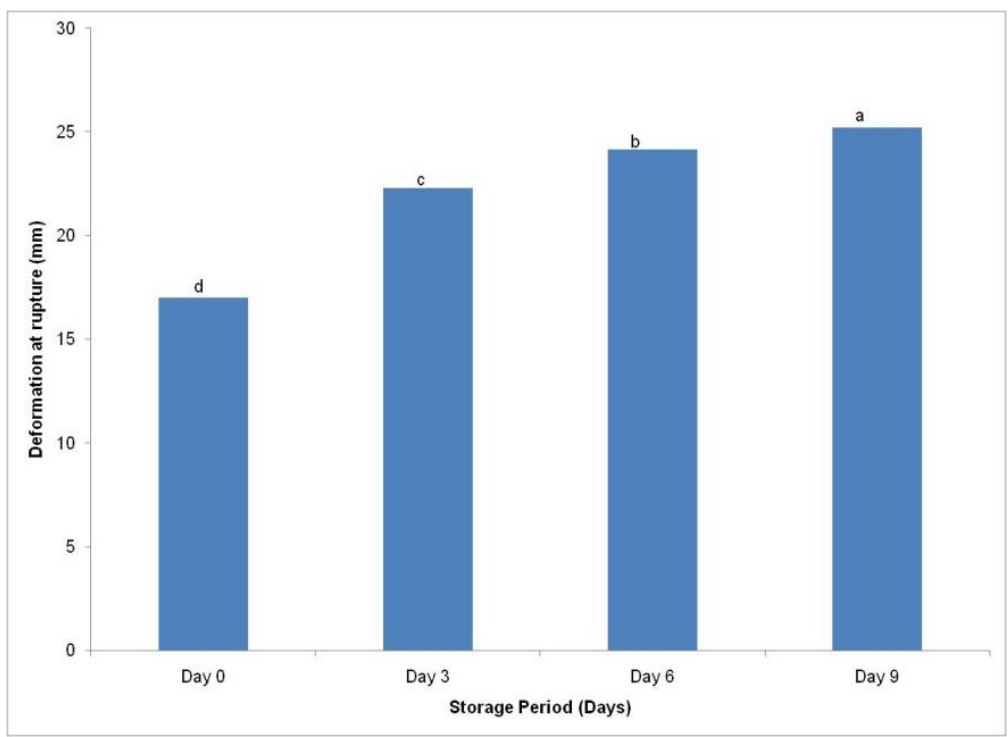

Figure 5: Effects of storage duration on the deformation at rupture of Bello eggplant fruit Columns with the same common letters means that they are not significant different at $(\mathrm{P} \leq 0.05)$.

\subsection{Fruit Toughness}

The chart presented in Figure 6 showed that storage period had significant effect $(\mathrm{P} \leq 0.05)$ on Bello fruit toughness. Bello fruit toughness increased significantly between 3 and 6 days of storage, however, there was no significant difference between storage $0 \mathrm{~d}$ and $9 \mathrm{~d}$. The maximum and minimum values of Bello fruit toughness were 0.270 and $0.403 \mathrm{~mJ} / \mathrm{mm}^{3}$ for $0 \mathrm{~d}$ and $9 \mathrm{~d}$ storage period. From the plot in Figure 6, it can be seen that toughness decreases after $6 \mathrm{~d}$ of storage period. This could be attributed to the deterioration of the Bello fruits, leading to the breakdown of the fruit epicrap strength. Therefore, the inconsistency in the fruit toughness during may be attributed to weaken of the fruit epicarp after storage day 6 , caused by enzymatic reactions. Apart from the increased in the firmness of the fruit epicarp during the initial storage period, another factor that could be responsible for the increased in the fruit toughness is the shrinkage in the fruit size and 
mass during the storage at the high temperature. According to Fricke and Wright, (2016) small seeds usually had the highest tissue densities across all crops species; therefore, seed toughness strongly decreases as its mass increases. In a research they reported that smaller seeds had higher specific toughness (2340 times greater) than larger seeds. Similar results were recorded by Ashtiani et al., (2016) for Siah-e-Mashhad eggplant fruit, where the fruit's pulp toughness increased from $0.113 \mathrm{Nm}$ to $0.146 \mathrm{Nm}$ during 9 storage days. But on the contrary Arendse et al., 2014 reported $53.56 \%$ decreased in the toughness of pomegranate fruits stored for 5 months in cold storage condition.

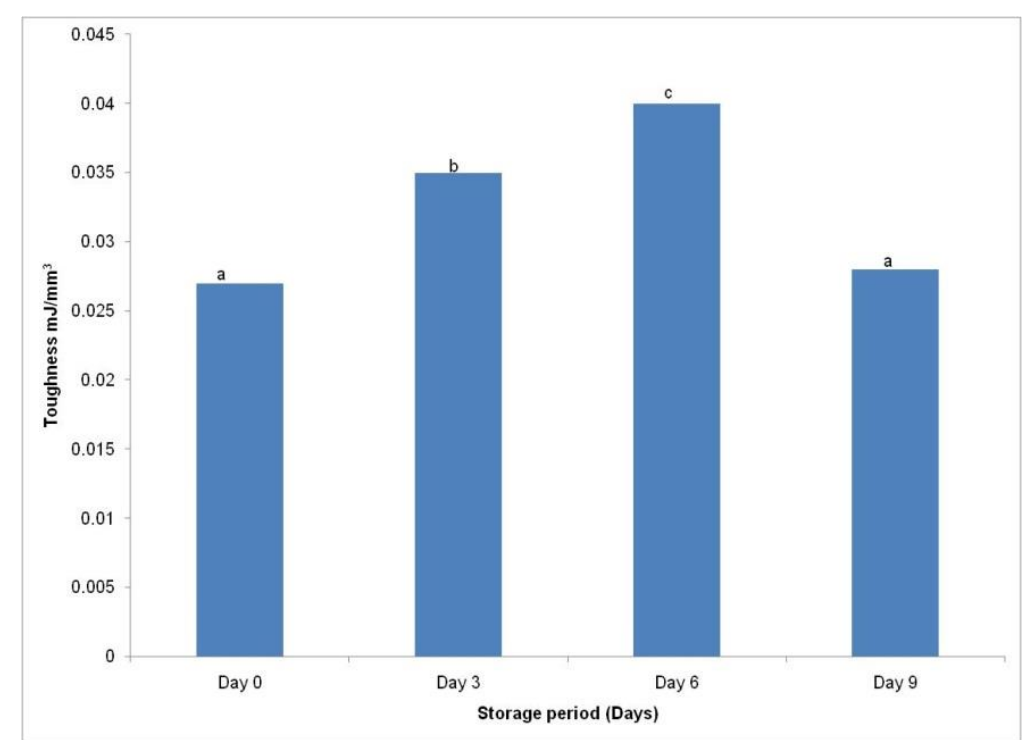

Figure 6: Effects of storage duration on the toughness of Bello eggplant fruit Columns with the same common letters means that they are not significant different at $(\mathrm{P} \leq 0.05)$.

\section{Conclusion}

In this study, some mechanical properties of Bello eggplant fruit were assessed over the course of a 9-day storage period. The results obtained from the mechanical tests demonstrated that mechanical parameters of Bello fruit are highly dependent on storage duration. Apart from the fruit toughness and deformation at rupture, the three remaining mechanical parameters (rupture force, rupture energy and power) decreased monotonically with the increasing of storage time. The rupture force decreased from $812 \mathrm{~N}$ and $411 \mathrm{~N}$; rupture energy declined from $5.58 \mathrm{Nm}$ to $3.11 \mathrm{Nm}$ (46.75 decrease); while the fruit toughness increased from $0.270 \mathrm{~mJ} / \mathrm{mm}^{3}$ and $0.403 \mathrm{~mJ} / \mathrm{mm}^{3}$. The findings of this study are useful in designing of eggplants' processing and packaging systems.

\section{References}

[1] Allende, A., Desmet, M., Vanstreels, E., Verlinden, B.E. and Nicolaï, B.M. (2004). Micromechanical and geometrical properties of tomato skin related to differences in puncture injury susceptibility. Postharvest Biology and Technology, 34: 131-141.

[2] Alozie S.O., Sharma R.P. and Salunkhe D.K. (1978). Inhibition of Rat Cholinesterase Soenzymes In Vitro and In Vivo by Potato Alaloill and Chaconine. Utah State University, Logan, UT 84322, USA: Interdepartmental Toxicology Programme. 
[3] Arendse, E., Fawole, O.A. and Opara, U.L. (2014). Influence of storage temperature and duration on postharvest physico-chemical and mechanical properties of pomegranate fruit and arils, CyTAJournal of Food, 12(4): 389-398.

[4] Ashtiani, S.M., Golzarian, M.R., Motie, J.B., Emadi, B. Jamal, N N. and Mohammadinezhad, H. (2016). Effect of Loading Position and Storage Duration on the Textural Properties of Eggplant, International Journal of Food Properties, 19(4): 814-825,

[5] Brusewitz, G. H., Pitt, R. E. and Gao. Q. (1989). Effects of storage time and static pre loading on the rheology of potato tissue. Journal of Texture Studies, 20(3): 267-284.

[6] Cen, H., Lu, R., Mendoza, F., Beaudry, R.M. (2013). Relationship of the optical absorption and scattering properties with mechanical and structural properties of apple tissue. Postharvest Biology and Technology, 85: 30-38.

[7] Dan, H. and Kohyama, K. (2007). Characterization of cucumber cultivars by mechanical stress distributions during the compression process. Japan Agricultural Research Quarterly, 41: 115121.

[8] Eboibi, O. and Uguru, H. (2017). Storage conditions effect on physic-mechanical properties of Nandini cucumber. International Journal of Engineering and Technical Research, 7(10): 75-82.

[9] Emadi, B., Kosse, V. and Yarlagadda, P.K.D.V. (2005). Mechanical properties of pumpkin. International Journal of Food Properties, 8: 277-287

[10] Fricke, E.C. and Wright, S.J. (2016). The mechanical defence advantage of small seeds. Ecology Letters, 1 -5. doi: 10.1111/ele.12637

[11] Hornal, D., Timpo, S. and Guillaume, G. (2007). Marketing of Underutilized crops: The case of the African eggplant (Solanum aethiopium) in Ghana.

[12] Hu, W., Jiang, A., Tian, M., Liu, C. and Wang, Y. (2010). Effect of ethanol treatment on physiological and quality attributes of fresh-cut eggplant. Journal of the Science of Food and Agriculture, 90: 1323-1326.

[13] Jahangiri, M., Hassan-Beygi, S R., Aboonajmi, M and Lotfi, M. (2016). Effects of storage duration and conditions on mechanical properties of Viola cucumber fruit under compression loading. Agricultural Engineering International: CIGR Journal, 18 (2):323-332.

[14] Li, Z., Li, P., and Liu, J. (2010). Effect of tomato internal structure on its mechanical properties and degree of mechanical damage. African Journal of Biotechnology, 9: 1816-1826.

[15] Li, Z., Yang, H., Li, P., Liu, J., Wang, J. and Xu, Y. (2013). Fruit biomechanics based on anatomy: A Review. International Agrophysics, 27: 97-106.

[16] Khazaei, J., Rasekh, M., Borghei, A.M. (2002). Physical and mechanical properties of almond and its kernel related to cracking and peeling. An ASAE Meeting Presentation, Paper No 026153.

[17] Kays, S.J. and Paull, R.E. (2004). Postharvest Biology. Exxon Press, Athens, Georgia.

[18] Masoudi, H., Tabatabaeefar, A. and Borghaee, A. M. (2007). Determination of storage effect on mechanical properties of apples using the uniaxial compression test. Canadian Biosystems Engineering Journal, 49: 329-333.

[19] Mohsenin, N. N. (1986). Physical properties of plant and animal materials. New York: Gordon and Breach Publishers.

[20] Msogoya, T. J., Majubwa, R. O. and Maerere, A. P. (2014). Effects of harvesting stages on yield and nutritional quality of African eggplant (Solanum aethiopicum L.) fruits. Journal of Applied Biosciences 78:6590 - 6599

[21] Nyorere, O. and Uguru, H. (2018). Effect of finger size and variety on mechanical properties of intact plantain (musa paradisiaca) finger under quasi-static loading. Advances in Research 16(2): $1-6$.

[22] Olaniyan, A.M. and Oje, K. (2002). Strength properties of shea-butter nuts under compressive loading. Nigerian Journal of Technology, 21(1):9-17.

[23] Osei M.K., Banful1 B., Osei C K. and Oluoch M. O. (2010). Characterization of African eggplant for morphological characteristics. J. Agric. Sci. Technol., 4 (3): 33-37 
[24] Ozturk, I., Ercisli, S., Kalkan, F. and Demir, B. (2009). Some chemical and physico-mechanical properties of pear cultivars. African Journal of Biosystems, 8: 687-693.

[25] Pérez-López, A., Chávez-Franco, S.H., Villaseñor-Perea, C.A., Espinosa-Solares, T., HernándezGómez, L.H., Lobato-Calleros, C. (2014). Respiration rate and mechanical properties of peach fruit during storage at three maturity stages. Journal of Food Engineering, 142: 111-117.

[26] Salvador, A., Sanz, T. and Fiszman, S.M (2007). Changes in color and texture and their relationship with eating quality during storage of two different dessert bananas. Postharvest Biology and Technology, 43: 319-325

[27] Sanchez-Mata M-C., Yokoyama W. E., Hong YJ. and Prohens J. (2010). $\alpha$-Solasonine and $\alpha$ Solamargine contents of Gboma (Solanum macrocarpon L.) and scarlet (Solanum aethiopicum L.) eggplants, J. Agric. Food chem., 58 (9): 5502-5508

[28] Redgwell, R.J. and Fischer, M. (2002). Fruit texture, cell wall metabolism and consumer perceptions. In: Knee, M. (Ed.), Fruit Quality and its Biological Basis. Sheffield Academic Press Ltd., Sheffield, UK, pp. 46-88.

[29] Singh, K.K. and Reddy, B.S. (2006). Post-harvest physico-mechanical properties of orange peel and fruit. Journal of Food Engineering, 73:112 - 120.

[30] Singh, A. P., Luthria, D., Wilson. T., Vorsa, N., Singh, V., Banuelos, G. S., and Pasakdee, S. (2009). Polyphenols content and antioxidant capacity of eggplant pulp. Food Chemistry, 114: 955-961.

[31] Singh, A.P., Luthria, D., Wilson, T., Vorsa, N., Singh, V., Banuelos, G.S. and Pasakdee, S. (2009). Polyphenols content and antioxidant capacity of eggplant pulp. Food Chemistry, 114, 955-961.

[32] Steffe, J. E. (1996). Rheological Methods in Food Process Engineering. (Second Edition). Freeman Press, USA.

[33] Tabatabaekoloor, R. (2014). Bio-mechanical Behavior of Kiwifruit as Affected by Fruit Orientation and Storage Conditions. Proceedings International Conference of Agricultural Engineering, Zurich.

[34] Tindal, H.D. (1965). Fruits and Vegetables in West Africa. London: Oxford University Press) $2^{\text {nd }}$ edn., 5(8): 105

[35] Uguru, H. and Iweka, C. (2019). The influence of size and variety on the compressive behaviour of groundnut kernel. Direct Research Journal of Agriculture and Food Science, 7(3): 62-69

[36] Varela, P., Salvador, A. and Fiszman, S. (2007). Changes in apple tissue with storage time: rheological, textural, and microstructural analyses. Journal of Food Engineering, 78: 622-629

[37] Yurtlu, Y. B., and Erdogan, D. (2005). Effect of storage time on some mechanical properties and bruise susceptibility of pears and apples. Turkish Journal of Agriculture and Forestry, 29(6): 469482.

[38] Zdunek, A., Cybulska, J., Konopacka, D. and Rutkowski, K. (2010). New contact acoustic emission detector for texture evaluation of apples. Journal of Food Engineering, 99(1): 83-91.

\footnotetext{
*Corresponding author.

E-mail address: erobo2011@ gmail.com
} 